\title{
Morphology and sedimentology of the Itaipú Embayment - Niterói/RJ
}

\author{
MARCUS VINICIUS S. SALVADOR ${ }^{1}$ and MARIA AUGUSTA M. DA SILVA ${ }^{2}$ \\ ${ }^{1}$ CONSUB - 24050-090 Ilha da Conceição, Niterói, RJ \\ ${ }^{2}$ Departamento de Geologia, UFF, Campus da Praia Vermelha, Boa Viagem - 24210-340 Niterói, RJ
}

Manuscript received on December 6, 2000; accepted for publication on October 4, 2001; presented by DIOGENES A. CAMPOS

\begin{abstract}
Bathymetric and sedimentological data from water depths between 3 and 28 meters are the basis of a detailed bathymetric map of the Itaipú Embayment and an understanding of its sedimentary dynamics. Shallower than 16 meters the contours are parallel to the shoreline whereas the morphology of the deeper bottom is influenced by the Menina, Mãe, and Pai islands. Medium sand is prevalent, with local variations in more protected or less protected areas. Minor amount of black mud possibly derives from the Itaipú Lagoon. Siliciclastic granules and pebbles may be relict. The Itaipú Embayment's bottom morphology is controlled by stormy waves and the calmer easternmost part of the embayment presents a tendency to accumulate finer sediments.
\end{abstract}

Key words: coastal dynamics, coastal sedimentation, geomorphology, quaternary.

\section{INTRODUCTION}

The main objective of this work is to characterize the morphology and sedimentology of the Itaipú Embayment (Niterói, Rio de Janeiro State). Despite the enormous growth of population along the shoreline in Niterói, no systematic work has ever been carried out in this embayment and, consequently, this original research aims to contribute to projects of coastal planning and management.

The study area extends from the Imbuí Point on the west to the Itaipú Point on the east, containing the Piratininga, Camboinhas and Itaipú beaches, and its seaward limit corresponds to the aligned islands of Pai, Mãe, and Menina (Fig. 1). The water depth varies from a minimum of about 3-4 m (just seaward of the average breaking wave zone) to a

Correspondence to: M. Augusta M. da Silva

E-mail: augusta@igeo.uff.br maximum of $28 \mathrm{~m}$, all of these depths pertaining to the shoreface environment. The Itaipú Embayment, a clastic wave-dominated environment, experiences a micro-tidal semi-diurnal variation with maximum spring tidal fluctuation of $1,4 \mathrm{~m}(\mathrm{DHN}$ 1974). Coastal current velocities rarely exceed 10 cm/s (ECP 1979, in: Lavenère-Wanderley 1999).

There is a regional NE/SW structural alignment of Precambrian rocks that comprise the floor of the Itaipú Embayment resulting from MesozoicCenozoic tectonic reactivation that was characterized by the parallel emplacement of Cretaceous diabase dikes (Asmus and Ferrari 1978, Ferrari 1990). Quaternary sandy sediments make up the barrier beaches (DRM/RJ 1981). Of the two lagoons, Piratininga and Itaipú (Fig. 1), only the Itaipú has an open tidal inlet through the Itaipú Canal which was artificially opened at the end of the 70s. Local 


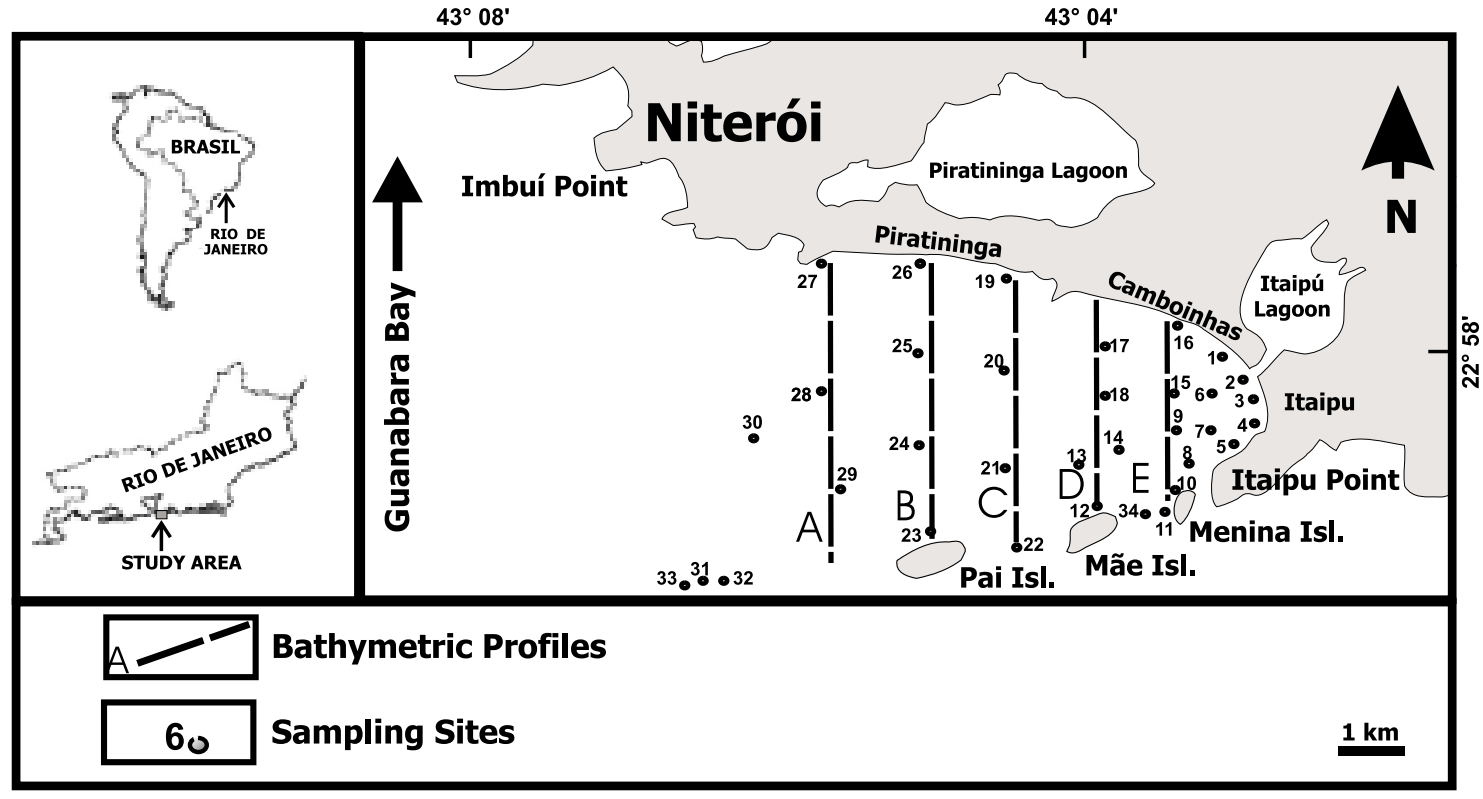

Fig. 1 - Location of the Itaipú Embayment (Niterói/Rio de Janeiro) and sampling sites and bathymetric profiles.

drainages to the lagoons do not deliver great amounts of sediment. Waves coming from $\mathrm{S}$ and $\mathrm{SE}$ reach the Itaipú Embayment after suffering diffraction by the Itaipú Point and the islands; the important SW storm waves are less frequent, occurring mainly in autumn and winter, but play an important role in the dynamics of this embayment and on the beaches (LavenèreWanderley 1999). The work of Muehe and Sucharov (1981), about sediment transport in the continental shelf near the Maricá Islands (Rio de Janeiro), states that, although not frequent, southwest winds associated with cold fronts present the maximum velocities and cause the highest storm waves observed in this region. Similar south winds, also from cold fronts, play an important role in shaping the bottom morphology between the Pai, Mãe and Menina Islands (Muehe and Sucharov 1981).

The Itaipú Embayment's bottom morphology as mapped in 1987 by the Diretoria de Hidrografia e Navegação (DHN) was used as reference in this work. Muehe et al. (1977), Muehe and Sucharov (1981), and Muehe $(1984,1989)$ present information about the topography of beaches and the inner shelf based on profiles located at the center of the shorelines between Niterói and Cabo Frio and sediment distribution along these profiles. Our work is a more detailed description of the submarine morphology and the sedimentary cover of the Itaipú Embayment.

This coastline, and other shorelines of Rio de Janeiro, are undergoing enormous growth of population, coupled with intense deforestation of hill slopes and basic sewage treatment that is not appropriate. Itaipú is a traditional fishing village, and both the beaches and the calm waters of the embayment are an important leisure area for the communities of Niterói, other nearby towns, and the city of Rio de Janeiro.

\section{MATERIALS AND METHODS}

The submarine morphology of the Embayment was initially characterized through two 1987 DHN Charts (FB-1511-002/87, FB-1511-003/87), with bathymetric lines contoured at every $50 \mathrm{~m}$. On the basis of these data, a map was produced (1:10.000), using the software Autocad 14 (datum Córrego Alegre) with isobaths spaced at intervals of one meter. New bathymetric data were collected from specific 


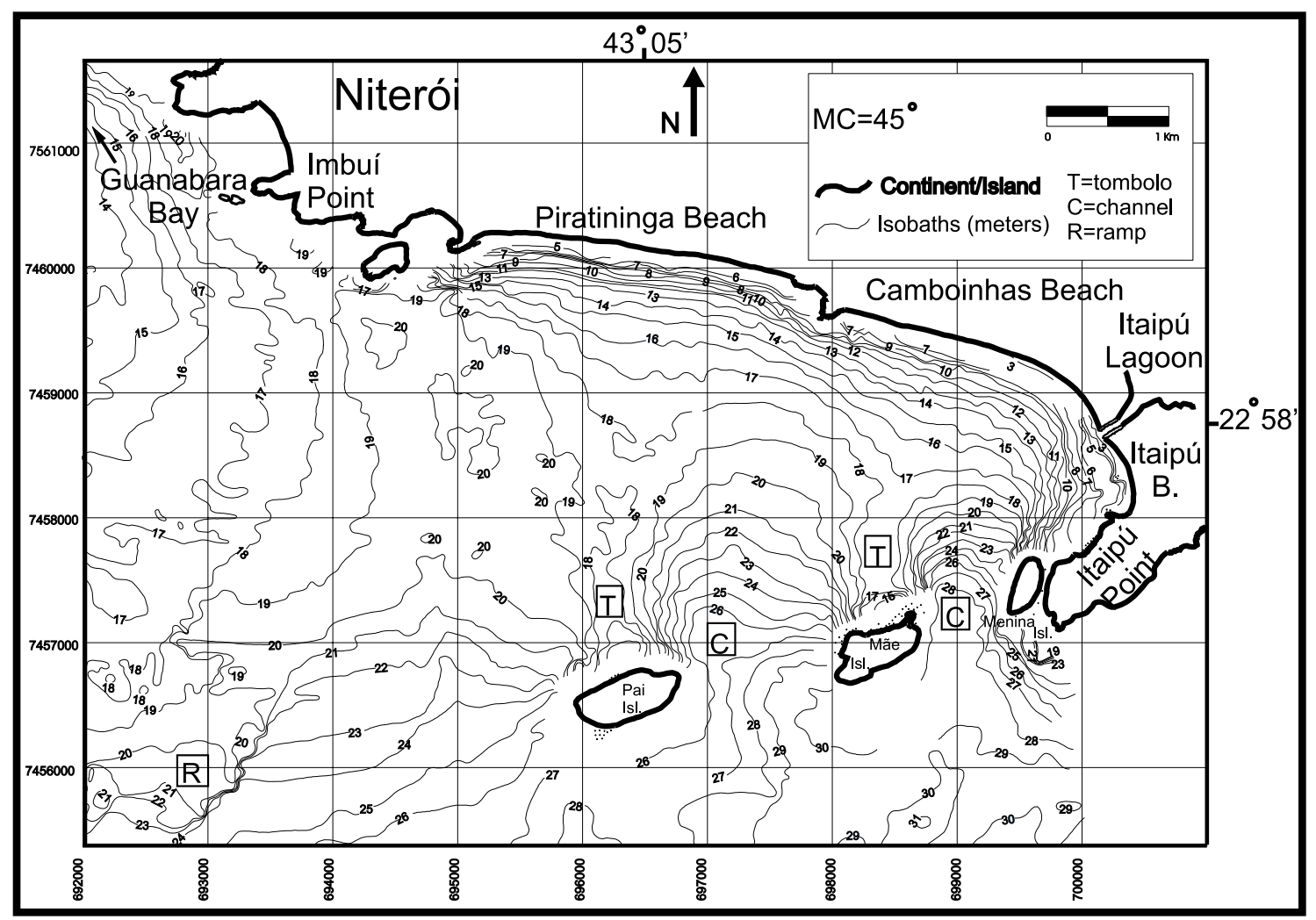

Fig. 2 - Bathymetric map of the Itaipú Embayment based on data collected during this work combined with data from DHN (1987).

sites not covered by previous DHN works, mainly in the vicinity of the Itaipú Canal in water depths between 3 and $6 \mathrm{~m}$. The results of the field work associated with the 1987 DHN charts gave rise to the bathymetric map presented in Fig. 2. For the field work, the following equipment was utilized: DGPS Fulgro Seastar with satellite "Link", computer with Hydro 6.0 for navigation, Raytheon 719-C.

Based on the topography shown in this map, five bathymetric profiles were selected along which we accomplished sampling (Fig. 1). A total of 34 samples were collected using a Dietz-Lafond sampler and positioned with a GPS. The samples were sieved for grain size analysis and interpreted with the program Grânulo (Lagemar - UFF), according to Folk and Ward (1957). Samples of fine sediments were sent to the Geosciences School, Queen's University of Belfast (Northern Ireland), for geochemical analyses as described by Bernas (1968).

\section{RESULTS AND DISCUSSION}

SubMARINE MORPHOLOGY OF THE ITAIPÚ EMBAYMENT

Between 3 and $16 \mathrm{~m}$ water depth, the trend of the submarine morphology is parallel to the coast (Fig. 2 ), but deeper than the $16 \mathrm{~m}$ isobath the bottom morphology is distinctly different. North-trending channels are present between the islands at depths of about 26 to $28 \mathrm{~m}$, becoming shallower shoreward. A less well defined channel also occurs west of Pai Island, and at about $2500 \mathrm{~m}$ to the southwest there is a ramp with a slope gradient of $1: 10$, changing from a depth of $21.5 \mathrm{~m}$ to $24.5 \mathrm{~m}$ within a distance of $30 \mathrm{me}-$ ters. The position of this feature coincides with the northeast/southwest regional structural alignment of the three islands, suggesting that such feature is also part of the basement.

Between the islands of Pai and Mãe and the 


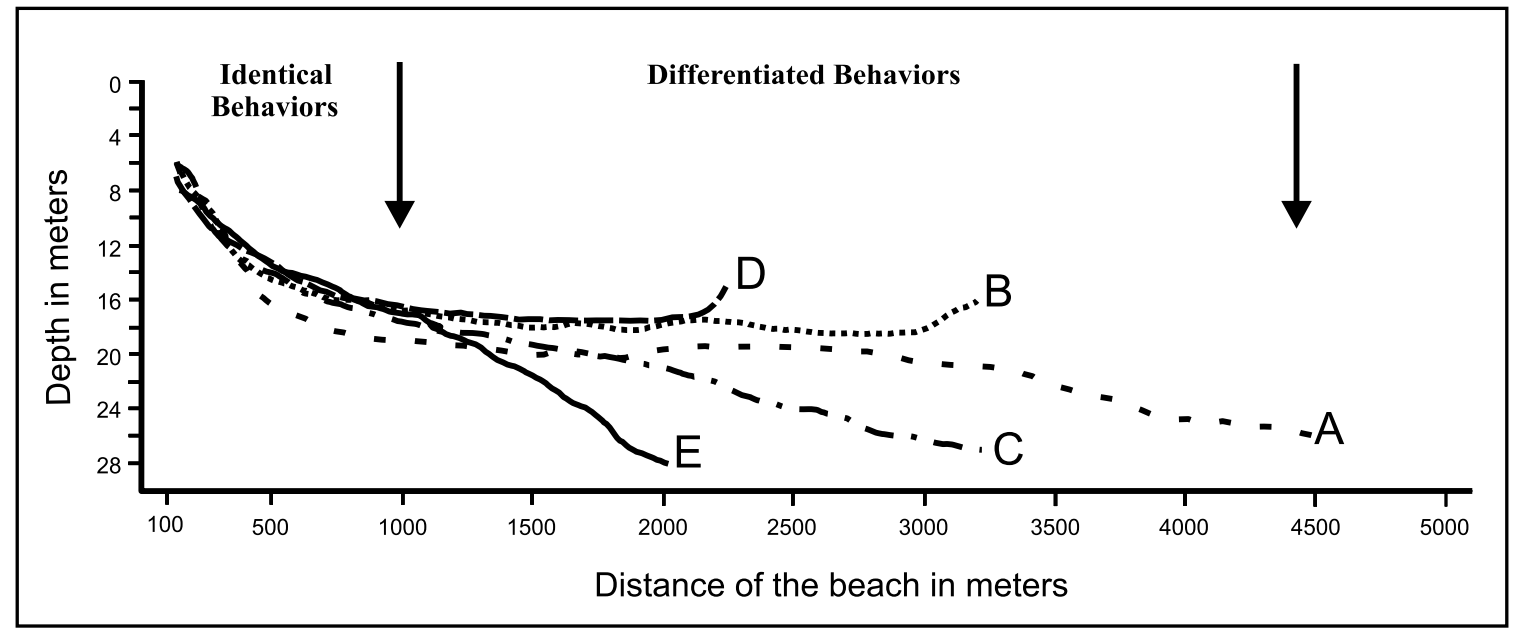

Fig. 3 - North-south oriented profiles characterizing the bottom of the Itaipú Embayment (location in figure 1).

shore, at water depths of about $18 \mathrm{~m}$, bathymetric highs trend perpendicular to the shoreline for a distance of about $1500 \mathrm{~m}$ from the islands (Fig. 2). The bottom morphology of these highs is reminiscent of a tombolo, a shadow zone for wave propagation and a calm location for accumulation of sediments.

Five mutually parallel north/south profiles are shown in Fig. 3. Profile A is very steep and deep within the first $1 \mathrm{~km}$ from the beach probably governed by southwest high-energy waves associated with cold fronts as observed on the nearby Piratininga beach profiles (Bastos and Silva 1995). Farther seaward than $1 \mathrm{~km}$, profiles A, C and E (Fig. 3) present a uniform seawards inclination and they pass between the islands with channel-like shapes, whereas profiles B and D (Fig. 3) located between the islands and the shore show a concave shape due to the sediment accumulation near the islands as in a tombolo. The existence of these channels is due basically to wave diffraction as described by Duxbury and Duxbury (1993). Although diffraction occurs with all the waves, only storm waves can reach the local sea bottom to mobilize sediments. The channel between Pai Island and the ramp (Fig. 2) may also have originated by wave diffraction, though during a lower sea level stand. These five profiles resemble what Barrel (1912, apud Niedoroda et al. 1985) define as shoreface, in which a concave surface just beyond the surf zone slopes offshore with a gradient of 1:200.

\section{Sediment Distribution}

The Itaipú Embayment bottom is mainly covered by quartz-rich sand; granules and pebbles of biological detritus are minor (except in samples 31 and 32), and silt and clay fractions occur only locally (samples 11 and 34).

Although grain size analysis shows that the quartzose sandy sediments are anything from very fine to coarse, most of the embayment floor, at water depths less than $30 \mathrm{~m}$, is covered by medium size sand consisting of well reworked and shiny quartz (Fig. 4). Fine sand occurs as a long strip beginning at the nearshore of the center of the Camboinhas beach and extending towards the Itaipú beach, plus other minor isolated bodies (Fig. 4).

The occurrence of fine sand is most probably related to reworking of tidal inlet sand by storms; storms working in conjunction with ebb tidal currents move the sand out which then forms bars at the inlet mouth. Lagoonal-derived finer sediment is seen as plumes coming out of the Itaipú inlet after heavy rainstorms, (especially in summer time) and moving to deeper waters of the embayment (Silva et al. 1997). 


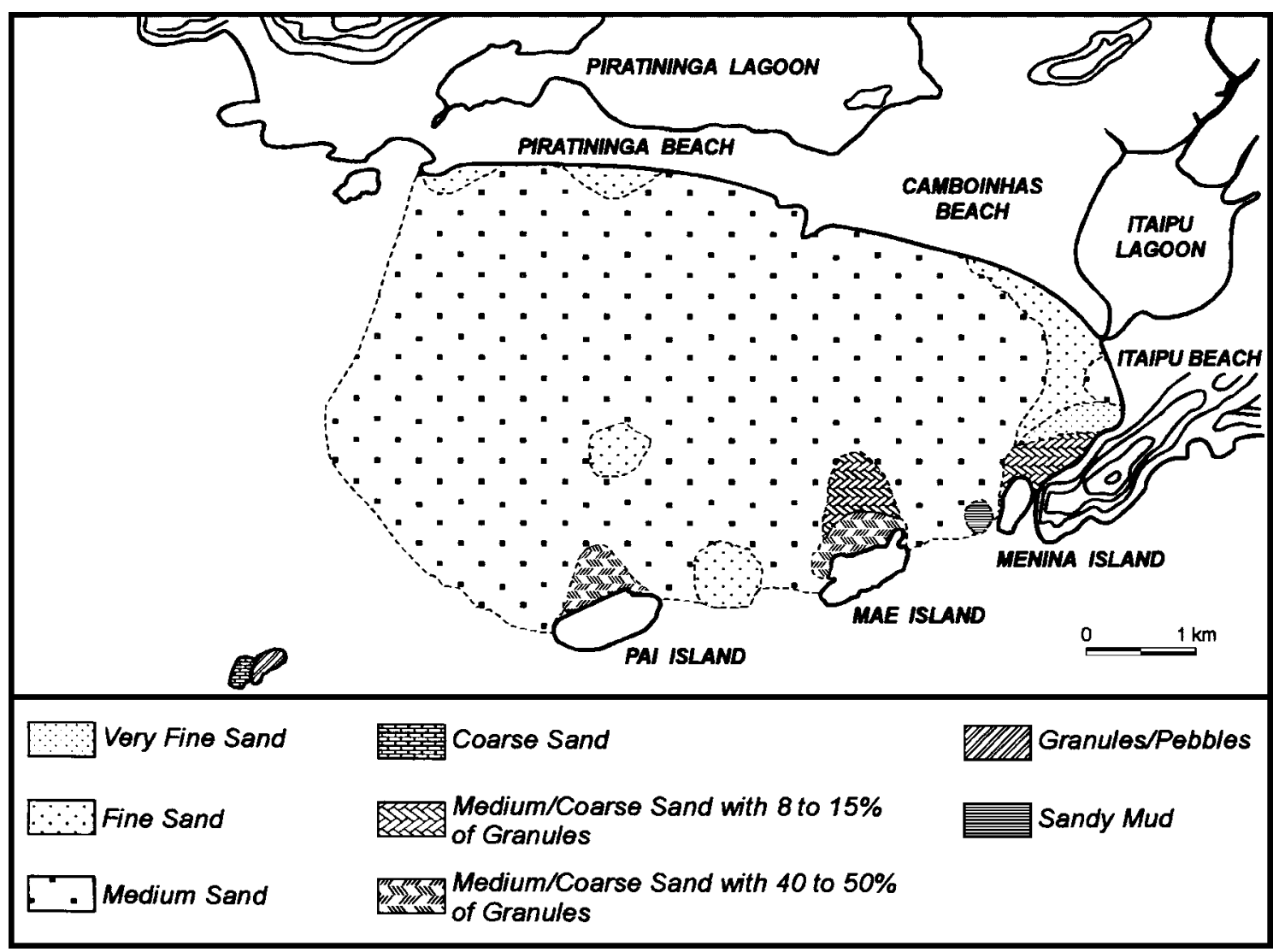

Fig. 4 - Distribution of bottom sediments in the Itaipú Embayment.

Submarine regions off the eastern part of Piratininga Beach (water depths less than $3 \mathrm{~m}$ ) and off the western part of Camboinhas do not contain fine sand, possibly as a result of diffraction of south-advancing storm waves passing through the Pai and Mãe Islands, causing dissipation of wave energy where fine sands persists, and concentration of wave energy in regions of coarser sand.

Near the Itaipú Point and on the landward side of the islands, medium to coarse sand and granules predominate, with abundant biological detritus (Fig. 4), eroded from nearby islands and cliffs.

About 2500 meters west of Pai Island, where water is deeper than $20 \mathrm{~m}$, the bottom sediment consists of quartz-rich coarse sand and granules (Fig. 4); a diabase pebble was collected $150 \mathrm{~m}$ northeastwards of this site. The coarser sediments are probably relict deposits left as the shoreline retrograded during the last stages of the Post-Glacial Transgression, as proposed by Muehe (1989) for similar nearby deposits.

Muddy sediment was found only in two samples (11 and 34) collected between Mãe and Menina Islands (Fig. 4). Black color, characteristic of an anoxic environment, probably indicates a contribution of fine lagoonal sediment through the Itaipú Inlet after heavy storm rains, especially at times of ebb tides (Silva et al. 1997). The plume of fine sediment survives at water depths around $28 \mathrm{~m}$, below normal wave base. The concentrations of $\mathrm{Ca}, \mathrm{Mg}$, $\mathrm{Na}, \mathrm{K}, \mathrm{Fe}, \mathrm{Mn}, \mathrm{Zn}, \mathrm{Cu}, \mathrm{Cr}, \mathrm{Ni}$ and $\mathrm{Pb}$ were investigated for the recognition of potential sources (Table I). The concentrations of $\mathrm{Cu}, \mathrm{Cr}$ and $\mathrm{Ni}$ proved to be useful for correlation to nearby source environments 
TABLE I

Results of geochemical analyses carried on samples from the Itaipú Embayment compared to nearby coastal areas.

\begin{tabular}{|c|c|c|c|c|c|c|c|c|c|c|c|}
\hline Samples & $\mathrm{Ca}$ & $\mathrm{Mg}$ & $\mathrm{Na}$ & K & $\mathrm{Fe}$ & Mn & $\mathrm{Zn}$ & $\mathrm{Cu}$ & $\mathrm{Cr}$ & $\mathrm{Ni}$ & $\mathrm{Pb}$ \\
\hline 11-Itaipú Embayment* & 43250 & 10500 & 1950 & 4950 & 37250 & 575 & 137.5 & 37.5 & 120 & 32.5 & 60 \\
\hline 34-Itaipú Embayment* & 33500 & 11750 & 17250 & 6000 & 36000 & 550 & 135 & 75 & 112.5 & 47.5 & 57.5 \\
\hline $\begin{array}{l}\text { Jurujuba Embayment } \\
\text { (maximum)* }\end{array}$ & 82500 & 20000 & 60000 & 15000 & 21250 & 412 & 338 & 212 & 230 & 79 & 122 \\
\hline $\begin{array}{l}\text { Jurujuba Embayment } \\
\text { (minimum)* }\end{array}$ & 2000 & 6250 & 6250 & 6875 & 11250 & 125 & 162 & 40 & 79 & 44 & 45 \\
\hline $\begin{array}{l}\text { Itaipú Lagoon } \\
(\text { maximum)** }\end{array}$ & & & & & 35250 & 155 & 85 & 35 & 227.5 & 35 & 30 \\
\hline $\begin{array}{l}\text { Itaipú Lagoon } \\
\text { (minimum)** }^{* *}\end{array}$ & & & & & 11000 & 102.5 & 32.5 & 12.5 & 117.5 & 15 & 5 \\
\hline Rio de Janeiro Port*** & & & & & & 138.4 & 418.6 & 104.7 & 48.9 & 13.3 & 93.4 \\
\hline $\begin{array}{l}\text { Close to centro of the } \\
\text { Bridge Rio/Niterói*** }\end{array}$ & & & & & & 166.1 & 199.5 & 43.3 & 25.1 & 8.4 & 41.7 \\
\hline Guanabara entrance $* * *$ & & & & & & 74.6 & 172.5 & 27.2 & 20.4 & 5.6 & 24.7 \\
\hline $\begin{array}{l}\text { Close to bridge and } \\
\text { port of Rio/Niterói**** }\end{array}$ & & & & & & & & 76.2 & 39.6 & & 96.8 \\
\hline
\end{tabular}

Obs.: values in ppm. - *Baptista Neto (1996); **Lavenère-Wanderley (1999); ***Perin, Fabris, Manente, Wagener, Hamacher and Scotto (1997) and ****Haekel, Schroeder, Felsen, Rebello, Moreira and Santelli (1985).

(Baptista Neto 1996, Haekell et al. 1985, LavenèreWanderley 1999, Perin et al. 1997). Cu values are similar to those in the Itaipú Lagoon and in parts of the Guanabara Bay; $\mathrm{Cr}$ and Ni resemble those in the lagoon and average values found in the Jurujuba Sound, Guanabara Bay. These preliminary geochemical results corroborate the observations that sediment plumes exiting through the Itaipú inlet are the main sources, although sediment in Guanabara Bay may contribute with small amounts of these elements.

\section{CONCLUSIONS}

The bottom morphology of the Itaipú Embayment is clearly controlled by the influence of Itaipú Point and by the Pai, Mãe, and Menina islands which are obstacles to wave propagation. Wave diffraction in- fluences the formation of channels between the islands, and sediment accumulations on the protected side of the islands, producing tombolo-like features. At depths below the $16 \mathrm{~m}$ isobath the average bottom gradient is $1: 200$, corresponding to the lower shoreface. Between 3 and $16 \mathrm{~m}$ the isobaths are parallel to the shoreline with a 1:90 gradient, which is quite steep for the upper shoreface (Barrel 1912, apud Niedoroda et al. 1985). To the Southwest, the ramping bottom morphology follows the trend of the Pai, Mãe, and Menina islands, suggesting control by the northeasterly grain of the basement.

The Itaipú Embayment sedimentary cover, mostly medium sand, is typical for the ocean side coast of Niterói. Other sediment includes coarser biodetrital deposits on the landward-facing side of the islands and at the base of the Itaipú Point, and minor isolated deposits of fine sand. Coarse terrige- 
nous sediment at 21 to $24 \mathrm{~m}$ is a relict from bottom reworking during the last sea transgression and retained behind a topographic barrier. Muddy sediment (over $60 \%$ of fine particles) in two samples has a source in the Itaipú Lagoon. Concentrations of $\mathrm{Cu}$, $\mathrm{Cr}$ and $\mathrm{Ni}$ in the mud suggest a source in seasonal plumes of sediments exiting through the Itaipú inlet.

Storm waves are the dominant control of the Itaipú Embayment bottom sedimentation and morphology, also influenced by the configuration of Precambrian basement. Quiet waters in the eastern part of the embayment provide a suitable environment for accumulation of fine sediment.

\section{ACKNOWLEDGMENTS}

Thanks are due to CAPES and FAPERJ for financial support. We also thank the several companies that made their equipments and personnel available for fieldwork and Dr. John MacAllister (Geosciences School of the Queen's University of Belfast) for the geochemical analyses. Our thanks to Dr. Luiz Gambôa, Paulo Maldonado and Haroldo Moraes Ramos of Petrobras for their overall support and to the students Carla Luiza dos Santos and Ricardo Henrique M. Santos for help during fieldwork.

\section{RESUMO}

Dados batimétricos e sedimentológicos coletados na enseada de Itaipú, em lâminas d'água variando de 3 a 28 metros, produziram um mapa batimétrico detalhado bem como permitiram a compreensão da dinâmica sedimentar dessa parte do litoral de Niterói. Os contornos batimétricos entre as isóbatas de 3 e 16 m exibem um comportamento paralelo a linha de costa, enquanto que a morfologia de fundo em profundidades superiores a $16 \mathrm{~m}$ é influenciada pelas ilhas da Menina, Mãe e do Pai. Areias médias predominam no fundo da enseada de Itaipú, com variações locais em áreas mais ou menos protegidas. Uma pequena ocorrência de lama preta possivelmente deriva da laguna de Itaipú. Grânulos e seixos siliciclásticos podem ser relíquias. A morfologia de fundo da enseada de Itaipú é controlada pelas ondas de tempestades e o seu lado mais calmo a leste apresenta tendência de acumular sedimentos mais finos.
Palavras-chave: dinâmica costeira, sedimentação costeira, geomorfologia, quaternário.

\section{REFERENCES}

Asmus HE and Ferrari AL. 1978. Hipóteses sobre as causas do tectonismo Cenozóico na região sudeste do Brasil. In: Aspectos estruturais da MARgem CONTINENTAL Leste E SUdeste do Brasil, Série REMAC, 4: 75-88, Rio de Janeiro.

Baptista Neto JA. 1996. Sedimentological evidence for human impact on a nearshore sedimentary environment: Jurujuba Sound, Rio de Janeiro State, Brazil. Doctoral Thesis. The Queen's University of Belfast, Northern Ireland. 321p.

Bastos AC And Silva CG. 1995. Study of morfological variations from beach profile in Piratininga Beach, Niterói, RJ - Congresso da ABEQUA, 5, Anais, Niterói, RJ, p. 205-210.

Bernas B. 1968. A New Method for Decomposition and Comprehensive Analysis of Silicates by Atomic Absorption Spectometry. Anal Chem 40: 1682-1686.

Departamento de Hidrografia e Navegação (DHN). 1974. Carta de Correntes de Maré - Baía de Guanabara.

Departamento de Hidrografia e Navegação (DHN). 1987. Cartas FB-1511-002/87 e FB-1511-003/87, Escala 1:10.000. Rio de Janeiro.

Departamento de Recursos Minerais do Estado do Rio DE JANeiro (DRM/RJ). 1981. Carta Geológica do Estado do Rio De Janeiro, Bloco Baía de Guanabara, Relatório Final. Vol. 1.

Duxbury AB and Duxbury AC. 1993. Fundamentals of Oceanography, Oxford: Wm. C. Brown Publishers, Oxford, p. 143-191.

Ferrari AL. 1990. A geologia do rift da Guanabara (RJ) na sua porção centro-ocidental e sua relação com o embasamento pré-cambriano. Congresso Bras. de Geologia, 36, Anais, Natal/RN, p. 2858-2872.

FolK RL AND Ward WC. 1957. Brazos River Bar: A study in the significance of grain size parameter. $\mathrm{J}$ Sedimentary Petrol 27: 3-27.

Haekell W, Schroeder F, Felsen V, Rebello AL, Moreira I and Santelli R. 1985. Cd, $\mathrm{Pb}, \mathrm{Cu}, \mathrm{Cr}$ and $\mathrm{Hg}$ in waters and sediments of the Guanabara Bay estuary. GKSS - Forschungszentrum Geesthacht, 
GMBH, p. 7-18.

LAVENÈRe-WANDERLEY AAO. 1999. Caracterização ambiental da Lagoa de Itaipú através do entendimento dos processos sedimentares em associação com a dinâmica atual. Dissertação de Mestrado, Curso de Geologia e Geofísica Marinha da Universidade Federal Fluminense, 141p.

Muene D. 1984. Evidência de recuo dos cordões litorâneos em direção ao continente no litoral do Rio de Janeiro. In: Lacerda, LD, Araujo DJD, CerqueIRA RE and Ture B. (eds), Restingas: Origem, Estruturas e Processos, CEUFF, Niterói, RJ, p. 75-80.

Muehe D. 1989. Distribuição e caracterização dos sedimentos arenosos da plataforma continental interna entre Niterói e Ponta Negra, RJ. Rev Bras Geocienc 19(1): 25-36.

Muehe D and Sucharov EC. 1981. Considerações sobre o transporte de sedimentos na plataforma continental nas proximidades das Ilhas Maricás, RJ. Rev Bras Geocien 11(4): 238-246.
Muehe D, Maranhão VA, Ribeiro Jr RN, Souza JRF AND Costa MGF. 1977. Características texturais dos sedimentos de algumas praias do litoral sul-oriental do Estado do Rio de Janeiro. An Acad Bras Ciênc, Rio de Janeiro, 49(3): 435-441.

Niedoroda AW, Swift DJP and Hopkins TS. 1985. The Shoreface. In: DAvis JR, RA, (ed). Coastal Sedimentary Environments, Springer-Verlag, New York, p. 533-624.

Perin G, Fabris R, Manente S, Wagener ARW, Hamacher C AND Scotto S. 1997. A five-year study on the heavy-metal pollution of Guanabara Bay sediments (Rio de Janeiro, Brazil) and evaluation of the metal bioavailability by means of geochemical speciation. Water Res 31(12): 3017-3028.

Silva MAM, Santos CL ANd Lavenère-WANDERLEy AA. 1997. Comportamento das areias com as mudanças sazonais no Canal de Itaipú (Niterói, RJ). Simpósio de Geologia do Sudeste, 5, Anais, Penedo, RJ, p. $43-44$. 